\title{
PENGARUH PENERAPAN ANGGARAN BERBASIS KINERJA \\ TERHADAP KINERJA KEUANGAN \\ (Penelitian Pada Dinas Bina Marga Provinsi Jawa Barat: Balai Pengelolaan Jalan Wilayah Pelayanan V)
}

Oleh:

Purnamasari

Dosen Ilmu Pemerintahan FISIP Unuversitas Galuh Ciamis

Jl. R.E. Martadinata No. 150, Ciamis 46274 Jawa Barat

Email:p.sari09@yahoo.com

\begin{abstract}
ABSTRAK
Penelitian ini difokuskan pada Pengaruh Anggaran Berbasis Kinerja tethadap Kinerja Keuangan (Penelitian Pada Dinas Bina Marga Provinsi Jawa Barat: Balai Pengelolaan Jalan Wilayah Pelayanan V). Permasalahan yang dihadapi dalam penelitian ini meliputi: 1) Bagaimana penerapan Anggaran Berbasis Kinerja pada BPJ Wilayah Pelayanan V?; 2) Bagaimana Kinerja Keuangan BPJ Wilayah Pelayanan V?; 3) Bagaimana pengaruh Anggaran Berbasis Kinerja terhadap Kinerja Keuangan pada BPJ Wilayah Pelayanan V? Metode yang digunakan dalam penelitian ini metode deskriptif dengan teknik penelitian sampel (seluruh populasi dijadikan sampel penelitian). Sedangkan untuk menganalisis data yang diperoleh digunakan Analisis Regresi Linier Sederhana, Analisis Koefisien Korelasi dan Uji Hipotesis menggunakan (Uji t). Hasil dari penelitian dan pengolahan data menunjukan bahwa Anggaran Berbasis Kinerja berpengaruh positif dan signifikan terhadap Kinerja Keuangan pada Balai Pengelolaan Jalan (BPJ) Wilayah Pelayanan V dengan besarnya pengaruh sebesar 56\% sedangkan sisanya $44 \%$ dipengaruhi faktor lain.
\end{abstract}

Kata Kunci: Anggaran Berbasis Kinerja, Kinerja Keuangan

\section{PENDAHULUAN}

Sejalan dengan yang diamanatkan dalam undang-undang No. 17 tahun 2003 tentang perimbangan keuangan Negara akan pula diterapkan secara penuh anggaran berbasis kinerja di sektor publik agar penggunaan anggaran tersebut bisa dinilai kemanfaatan dan kegunaannya oleh masyarakat. Undang-undang No.17 tahun 2003 menetapkan bahwa APBD disusun berdasarkan pendekatan prestasi kerja yang akan dicapai. Untuk mendukung kebijakan ini perlu dibangun suatu sistem yang dapat menyediakan data dan informasi untuk menyusun APBD dengan pendekatan kinerja Anggaran kinerja pada dasarnya merupakan sistem penyusunan dan pengelolaan anggaran daerah yang berorientasi pada pencapaian hasil atau kinerja. Adapun kinerja tersebut harus mencerminkan efisiensi dan efektifitas pelayanan publik, yang berarti harus berorentasi pada kepentingan publik. Melalui permendagri No. 13 tahun 2006 implementasi pradigma baru yang berorentasi pada prestasi kinerja dapat diterapkan dalam penyusunan APBD, baik dalam sistem akuntansi dan pengelolaan keuangan daerah.

Balai Pengelolaan Jalan (BPJ) Wilayah Pelayanan V merupakan salah satu unit pelaksana teknis pada Dinas Bina Marga Provinsi Jawa Barat. BPJ Wilayah Pelayanan V ini memiliki tugas melaksanakan sebagian fungsi Dinas dibidang teknis operasional pelayanan pengelolaan jalan untuk wilayah Tasikmalaya, Ciamis, Banjar dan Pangandaran. Sebagai salah satu organisasi pemerintah dan organisasi sektor publik, BPJ Wilayah Pelayanan V ini harus menyusun laporan pertanggungjawaban keuangannya. Penyusunan laporan keuangan tersebut berpedoman pada ketentuan pokok yang menyangkut pengelolaan keuangan dan otonomi daerah serta peraturan pelaksanaannya yang telah dikeluarkan oleh pemerintah pusat. Sedangkan dalam penerapannya diperkuat oleh peraturan daerah.

Penelitian ini difokuskan terhadap Analisa Kinerja Keuangan Daerah pada pelaksanaan Anggaran Berbasis Kinerja. Dari data yang diperoleh dari BPJ Wilayah Pelayanan V Tahun 2015 dapat dilihat bahwa tidak satupun dari pos belanja yang jumlah realisasi pengeluarannya mencapai anggaran. Berikut adalah informasi Realisasi Penggunaan Dana BPJ Wilayah Pelayanan V yang merupakan perincian dana per kegiatan pada tahun 2015: 
Tabel 1: Realisasi Penggunaan Dana

BPJ Wilayah Pelayanan V

Tahun 2015

\begin{tabular}{|c|l|c|c|c|c|c|}
\hline No & \multicolumn{1}{|c|}{ Uraian Kegiatan } & Anggaran (Rp) & Nilai SPJ (Rp) & $\begin{array}{c}\text { Sisa Anggaran } \\
(\mathbf{R p})\end{array}$ & $\begin{array}{c}\text { Realisasi } \\
(\mathbf{\%})\end{array}$ & $\begin{array}{c}\text { Target } \\
(\boldsymbol{\%})\end{array}$ \\
\hline 1 & $\begin{array}{l}\text { Peningkatan jalan \& } \\
\text { jembatan provinsi }\end{array}$ & $59.775 .727 .400,00$ & $54.320 .696 .111,00$ & $5.445 .031 .289,00$ & 90,87 & 100 \\
\hline 2 & $\begin{array}{l}\text { Rehabilitasi jalan \& } \\
\text { jembatan provinsi }\end{array}$ & $48.671 .099 .345,00$ & $46.151 .747 .924,00$ & $2.519 .351 .421,00$ & 94,82 & 100 \\
\hline 3 & $\begin{array}{l}\text { Pemeliharaan jalan \& } \\
\text { jembatan provinsi }\end{array}$ & $17.709 .572 .000,00$ & $17.431 .304 .230,00$ & $278.267 .770,00$ & 98,43 & 100 \\
\hline 4 & $\begin{array}{l}\text { Penyelenggaraan } \\
\text { administrasi } \\
\text { perkantoran }\end{array}$ & $203.427 .000,00$ & $188.486 .429,00$ & $14.940 .571,00$ & 92,66 & 100 \\
\hline 5 & $\begin{array}{l}\text { Peningkatan sarana \& } \\
\text { prasarana aparatur }\end{array}$ & $417.597 .000,00$ & $415.285 .000,00$ & $2.312 .000,00$ & 99,45 & 100 \\
\hline 6 & $\begin{array}{l}\text { Pemeliharaan sarana } \\
\& \text { prasarana aparatur }\end{array}$ & $135.194 .000,00$ & $122.553 .850,00$ & $12.640 .150,00$ & 90,65 & 100 \\
\hline
\end{tabular}

Sumber: SKPD BPJ Wilayah Pelayanan V

Dari data di atas dapat diketahui, bahwa realisasi penggunaan dana pada BPJ Wilayah Pelayanan $\mathrm{V}$ tidak terealisasi $100 \%$. Hal tersebut menunjukan bahwa kinerja keuangan lembaga tersebut belum maksimal, karena tidak sesuai dengan yang sudah direncanakan di awal. Dari data tersebut memberikan fakta bahwa penerapan anggaran berbasis kinerja masih belum dapat terealisasi dengan baik oleh BPJ Wilayah Pelayanan V yang merupakan objek dalam penelitian ini. Berdasarkan data yang ada, BPJ Wilayah Pelayanan V memiliki perubahan anggaran keuangan yang cukup besar dibandingkan dengan SKPD yang lainnya, namun ternyata realisasi anggaran belanja pada lembaga tersebut tidak mencapai target realisasi. Hal tersebut disebabkan karena adanya penawaran dari pihak kedua yang nilainya lebih rendah dari nilai anggaran terkait dengan tender proyek pemeliharaan jalan di wilayah pelayanan V. Selain itu hal lainnya yang menyebabkan anggaran tidak mencapai target adalah adanya perubahan harga BBM/Gas, bahan baku bangunan dan material jembatan, serta belanja lainnya. Berikut adalah beberapa kegiatan atau program yang nilainya dibawah nilai anggaran, disajikan dalam tabel di bawah ini:

Tabel 2: Kegiatan/Program yang Nilainya Dibawah Nilai Anggaran Tahun 2015

\begin{tabular}{|c|c|c|c|c|}
\hline No & Kegiatan/Program & $\begin{array}{c}\text { Anggaran } \\
\text { (Rp) }\end{array}$ & $\begin{array}{c}\text { Realisasi Anggaran } \\
\text { (Rp) }\end{array}$ & $\begin{array}{c}\text { Sisa Anggaran } \\
\text { (Rp) }\end{array}$ \\
\hline 1 & Peningkatan jalan di wilayah Kabupaten/Kota Tasikmalaya & $56.521 .807 .500,00$ & $51.071 .343 .055,00$ & $5.450 .464 .445,00$ \\
\hline 2 & Peningkatan jalan di Kabupaten Ciamis \& Kota Banjar & $3.117 .255 .400,00$ & $3.117 .088 .556,00$ & $166.844,00$ \\
\hline 3 & Rehabilitasi jalan di wilayah Kabupaten/Kota Tasikmalaya & $32.317 .531 .125,00$ & $30.753 .339 .357,00$ & $1.564 .191 .768,00$ \\
\hline 4 & Rehabilitasi jalan di Kabupaten Ciamis, Kota Banjar \& Kabupaten Pangandaran & $7.109 .170 .200,00$ & $6.584 .904 .699,00$ & $524.265 .501,00$ \\
\hline 5 & Rehabilitasi jalan di Kabupaten Kuningan & $9.078 .979 .400,00$ & $8.648 .376 .748,00$ & $430.602 .652,00$ \\
\hline 6 & Honorarium pegawai honorer/tidak tetap sub unit wilayah Kab/Kota Tasikmalaya & $1.833 .270 .000,00$ & $1.782 .186 .000,00$ & $51.084 .000,00$ \\
\hline 7 & Belanja BBM/Gas & $380.259 .000,00$ & $356.701 .400,00$ & $23.557 .600,00$ \\
\hline 8 & Belanja bahan baku bangunan di wilayah Kab. Ciamis \& Kota Banjar & $2.226 .048 .000,00$ & $2.219 .960 .560,00$ & $6.087 .440,00$ \\
\hline 9 & Belanja bahan \& material jembatan di Wilayah Kab. Kuningan & $196.141 .000,00$ & $184.219 .960,00$ & $11.921 .040,00$ \\
\hline 10 & Belanja jasa kantor & $96.000 .000,00$ & $81.289 .429,00$ & $14.710 .571,00$ \\
\hline \multirow[t]{2}{*}{11} & Belanja STNK & $35.100 .000,00$ & $23.469 .100,00$ & $11.630 .900,00$ \\
\hline & Total & 112.911.561.625,00 & 104.822.878.864,00 & 8.088.682.761,00 \\
\hline
\end{tabular}

Sumber: SKPD BPJ Wilayah Pelayanan V (data diolah)

Dari tabel di atas dapat dilihat bahwa terdapat beberapa kegiatan atau program yang nilainya dibawah nilai anggaran. Dari total yang dianggarkan terhadap kegiatan atau program tersebut di atas nilainya adalah sebesar Rp.112.911.561.625,00 namun yang terealisasi adalah sebesar Rp.104.882.878.864,00, dengan selisih yang nilainya sangat besar, yaitu Rp.8.088.682.761,00. Seperti contoh kegiatan peningkatan dan rehabilitasi jalan dibeberapa wilayah lingkup pelayanan wilayah $\mathrm{V}$ yang di tenderkan kepada pihak kedua, nilai penawarannya di bawah nilai anggaran. Sama halnya dengan kegiatan lainnya, seperti belanja 
pegawai, belanja BBM/Gas, belanja bahan baku bangunan dan material jembatan seta kegiatan lainnya yang nilainya dibawah nilai anggaran.

Dalam mewujudkan tata pemerintahan yang baik maka Pemerintah Daerah Provinsi Jawa Barat perlu mengikuti segala undangundang dan peraturan-peraturan yang berlaku. Salah satunya adalah Balai Pengelolaan Jalan (BPJ) Wilayah Pelayanan V perlu menerapkan prinsip-prinsip sistem anggaran berbasis kinerja yang ditetapkan secara bertahap mulai tahun 2005. Dengan tersedianya sumber daya manusia yang dapat memahami konsep pelaksanaan anggaran berbasis kinerja dan mengenai pentingnya penganggaran berbasis kinerja agar didukung dalam penerapan anggaran. Dengan adanya pemahaman yang benar dapat menghilangkan rasa saling curiga, tidak percaya dan terwujudnya sinergi antara pihak dalam mewujudkan anggaran yang berbasis kinerja bagi suatu pemerintah daerah secara baik dan benar sehingga pemerintahan yang baik dapat bersama-sama diwujudkan.

Beradasarkan uraian latar belakang penelitian di atas, maka penulis mengidentifikasikan masalah penelitian sebagai berikut: 1). Realisasi penggunaan dana BPJ Wilayah Pelayanan V tahun 2015 tidak mencapai target yang telah direncanakan di awal; 2). Penerapan anggaran berbasis kinerja pada BPJ Wilayah Pelayanan $\mathrm{V}$ belum maksimal; 3). Dengan belum tercapainya target realisasi penggunaan dana menunjukan bahwa kinerja keuangan BPJ Wilayah Pelayanan V belum maksimal. Maka berdasarkan identifikasi masalah penelitian di atas, maka tujuan penelitian ini adalah untuk mengetahui: 1).
Penerapan anggaran berbasis kinerja pada Balai Pengelolaan Jalan (BPJ) Wilayah Pelayanan V; 2). Kinerja keuangan Balai Pengelolaan Jalan (BPJ) Wilayah Pelayanan V; 3). Pengaruh anggaran berbasis kinerja terhadap kinerja keuangan pada Balai Pengelolaan Jalan (BPJ) Wilayah Pelayanan V.

\section{METODE PENELITIAN}

\section{Metode Penelitian yang Digunakan}

Peneliti menggunakan metode penelitian deskriptif, dimana metode peneltian deskriptif adalah salah satu metode penelitan yang banyak digunakan pada penelitian yang bertujuan untuk menjelaskan suatu kejadian.

Penggunaan metode deskriptif dalam penelitian ini adalah untuk menjelaskan dan menjabarkan fenomena terkait pengaruh anggaran berbasis kinierja terhadap kinerja keuangan yang terjadi pada Badan Pengelolaan Jalan (BPJ) Wilayah Pelayanan V Tasikmalaya.

Dalam desain penelitian akan tergambarkan mengenai rincian studi, pengukuran dan rancangan analisis hasil. Adapun desain penelitian yang akan diguanakan penulis adalah dengan langkah-langkah sebagai berikut:

1. Menjelaskan lebih dalam tentang hasil penelitian

2. Mengambil kesimpulan dan menyajikan saran.

\section{Operasionalisasi Variabel}

Agar usulan penelitian ini dapat dilaksanakan, maka perlu dipahami konsep operasionalisasi variabel yang dapat dilihat didalam tabel berikut ini:

Tabel 4: Operasionalisasi Variabel Penelitian

\begin{tabular}{|c|c|c|c|}
\hline Variabel & Konsep Variabel & Indikator & Skala \\
\hline $\begin{array}{l}\text { Anggaran } \\
\text { Berbasis } \\
\text { Kinerja }(X)\end{array}$ & $\begin{array}{l}\text { Performance budgeting (anggaran } \\
\text { yang berorentasi pada kinerja) adalah } \\
\text { sistem penganggaran yang berorentasi } \\
\text { pada output organisasi dan berkaitan } \\
\text { sangat erat dengan visi, misi dan } \\
\text { rencana strategi organisasi (Bastian, } \\
\text { 2006:171). }\end{array}$ & $\begin{array}{ll}\text { - } & \text { Masukan (input) } \\
\text { - } & \text { Keluaran (output) } \\
\text { - } & \text { Hasil (outcome) } \\
\text { - } & \text { Manfaat (benefit) } \\
\text { - } & \text { Dampak (Impact) }\end{array}$ & Interval \\
\hline $\begin{array}{l}\text { Kinerja } \\
\text { Keuangan (Y) }\end{array}$ & $\begin{array}{|lrr|}\text { Kinerja } & \text { keuangan } & \text { pemerintah } \\
\text { merupakan kemampuan } & \text { pemerintah } \\
\text { daerah dalam mengelola } & \text { keuangan } \\
\text { yang dituangkan dalam } & \text { Anggaran } \\
\text { Pendapatan dan Belanja } & \text { Daerah } \\
\text { (APBD) yang baik secara langsung } \\
\text { maupun secara tidak } & \text { langsung }\end{array}$ & $\begin{array}{ll}\text { - } & \text { Efisensi } \\
\text { - } & \text { Efektivitas } \\
\text { - } & \text { Ekonomis }\end{array}$ & Interval \\
\hline
\end{tabular}




\begin{tabular}{|l|l|l|l|}
\hline Variabel & Konsep Variabel Indikator & Skala \\
\hline & $\begin{array}{l}\text { mencerminkan kemampuan pemerintah } \\
\text { daerah dalam membiayai (1) } \\
\text { pelaksanaan tugas-tugas pemerintah, } \\
\text { (2) pembangunan dan (3) pelayanan } \\
\text { sosial masyarakat (Espinoza, 2014:55) }\end{array}$ & & \\
\hline
\end{tabular}

\section{Populasi dan Sampel}

Populasi merupakan keseluruhan dari unit analisa yang ciri-cirinya akan diduga. Popoulasi dalam penelitian ini adalah kepala bagian dan staff keuangan yang berjumlah 10 orang. Penentuan populasi ini didasarkan kepada tema penelitian, yaitu pihak-pihak yang berkaitan dengan pelaksanaan anggaran dan pihak yang menyusun pelaporan keuangan. Oleh karena itu, yang menjadi populasi dalam penelitian ini adalah bagian keuangan yaitu dari mulai kepala bagian beserta staff-staff nya.

Sampel merupakan bagian yang berguna bagi tujuan penelitian populasi dan aspekaspeknya. Dengan demikian besamya ukuran sampel yang diambil sebanyak 10 orang yang merupakan bagian keuangan yaitu dari mulai kepala bagian beserta staff-staffnya.

Hal ini didasarkan atas pendapat Arikunto (2006: 34) yang mengatakan bahwa "Untuk sekedar ancer-ancer, maka apabila subyeknya kurang dari 100 lebih baik diambil semua, sehingga penelitiannya merupakan penelitian populasi”. Dengan demikian sampel yang digunakan dalam penelitia ini adalah sebanyak 10 orang.

\section{Sumber dan Teknik Pengumpulan Data}

Sumber data dalam penelitian ini diperoleh dari data primer. Data primer merupakan sumber data penelitian yang diperoleh secara langsung dari sumber asli (tidak melalui perantara). Data primer adalah data yang berasal langsung dari responden. Data primer penelitian ini diperoleh dari kuesioner yang diisi responden secara langsung atau daftar pertanyaan kepada responden dari Bagian Keuangan BPJ Wilayah Pelayanan V Tasikmalaya, yaitu sebanyak 10 orang.

Pengumpulan data dapat dilakukan dalam berbagai setting dan berbagai sumber dan berbagai cara. Bila dilihat dari settingnya data dapat dikumpulkan pada setting alamiah (natural seting), pada laboratorium dengan metode eksperimen, di rumah dengan berbagai responden, dan lain-lain. Bila dilihat dari sumber datanya, maka pengumpulan data dapat menggunakan sumber primer dan sekunder. Sumber primer adalah sumber data yang langsung memberikan data kepada pengumpul data, dan sumber sekunder merupakan sumber yang tidak langsung memberikan data pada pengumpul data, misalnya lewat orang lain atau lewat dokumen.

Jenis data didalam penelitian ini adalah data primer, maka teknik pengumpulan data untuk penelitian ini dilakukan dalam beberapa tahap, yaitu:

1. Observasi

Observasi yang dilakukan penulis yaitu bertujuan untuk mengetahui pelaksanaan anggaran berbasis kinerja dan kinerja keuangan pada BPJ Wilayah Pelayanan V Tasikmalaya.

2. Penyebaran Kuesioner

Penyebaran kuesioner dilakukan di tempat penelitian, yaitu di BPJ Wilayah Pelayanan V Tasikmalaya. Kuesioner disebarkan kepada Kepala Bagian Keuangan beserta staff-staffnya.

Dalam suatu penelitian ilmiah, metode atau teknik pengumpulan data dimaksudkan untuk memperoleh bahan-bahan yang relevan, akurat, dan terpercaya, untuk memperoleh data primer yang diperlukan, teknik yang digunakan adalah pengisian kuesioner.

\section{Teknik Analisis Data}

Metode kuantitatif ini menggunakan statistik sebagai alat analisis datanya. Fungsi utama dari statistik adalah memanipulasikan dan meringkaskan data yang berupa angka serta membandingkan hasil yang diperoleh dengan kebetulan-kebetulan yang telah diperkirakan. Analisis data kuantitatif dan statistik ini mampu memperlihatkan hasil-hasil pengukuran yang cermat karena perhitungannya yang matematis. Namun kemudian hal ini tidak berarti bahwa kecermatan tersebut merupakan jaminan dalam keabsahannya atau validitasnya.

Korelasi ini dikemukakan oleh Karl Pearson tahun 1900 dalam Santoso (2003: 32). Kegunaannya untuk mengetahui derajat hubungan dan kontribusi variabel bebas (independen) dengan variabel terikat (dependen). 
Teknik analisis Korelasi PPM termasuk teknik statistik parametrik yang menggunakan interval dan ratio dengan persyaratan tertentu. Misalnya: data dipilih secara acak (random); datanya berdistribusi normal; data yang dihubungkan berpola linier; dan data yang dihubungkan mempunyai pasangan yang sama sesuai dengan subjek yang sama. Kalau salah satu tidak terpunuhi persaratan tersebut analisis korelasi tidak dapat dilakukan. Rumus yang digunakan Korelasi PPM adalah:

$$
r_{x y} \frac{n \sum X Y-\left(\sum X\right)\left(\sum Y\right)}{\sqrt{\left\{n \sum X^{2}-\left(\sum X\right)^{2}\right)\left(n \sum Y^{2}-\left(\sum Y\right)^{2} \mid\right.}}
$$

Keterangan:

$$
\begin{aligned}
\mathrm{X} & =\text { Anggaran Berbasis Kinerja } \\
\mathrm{Y} & =\text { Kinerja Keuangan } \\
\mathrm{N} & =\text { Jumlah sampel } \\
\mathrm{r}_{\mathrm{xy}} & =\begin{array}{l}
\text { Koefisien korelasi antara variabel } \mathrm{X} \\
\text { dan Variabel } \mathrm{Y}
\end{array}
\end{aligned}
$$

Korelasi PPM dilambangkan (r) dengan ketentuan nilai $r$ tidak lebih dari harga $(-1<r<+$ 1). Apabilah nilai $r=-1$ artinya korelasinya negatif sempurna; $r=0$ artinya tidak ada korelasi dan $r=1$ berarti korelasinya sangat kuat. Sedangkan arti harga $\mathrm{r}$ akan dikonsultasikan dengan tabel interpretasi nilai $r$ sebagai berikut:

Tabel 5: Interpretasi Koefisien Korelasi Nilai r

\begin{tabular}{|c|c|}
\hline Interval Koefisien & Tingkat Hubungan \\
\hline $0,80-1,000$ & Sangat Kuat \\
$0,60-0,799$ & Kuat \\
$0,40-0.599$ & Cukup Kuat \\
$0,20-0,399$ & Rendah \\
$0,00-0,199$ & Sangat Rendah \\
\hline
\end{tabular}

Sumber: Sugiyono (2011:250)

Metode analisis data yang dipakai dalam penelitian ini adalah metode analisa kuantitatif, di mana untuk mencapai tujuan pertama yaitu menganalisis pengaruh anggaran berbasis kinerja terhadap kinerja keuangan adalah dengan menggunakan analisis regresi sederhana. "Regresi sederhana berguna dilakukan terhadap model dengan satu variabel bebas, untuk diketahui pengaruhnya terhadap variabel terikat" (Santoso, 2007: 34).

Regeresi dilakukan untuk mengetahui sejauh mana variabel bebas mempengaruhi variabel terikat, pada analisis regresi ini terdapat satu variabel terikat dan satu variabel bebas, dalam penelitian ini yang menjadi variabel terikat adalah anggaran berbasis kinerja, sedangkan yang menjadi variabel bebas adalah kinerja keuangan.

Model penelitian dalam menguji varibelvariabel tersebut dapat disusun dalam fungsi atau persamaan sebagai berikut:

$$
\hat{\mathrm{Y}}=a+b X
$$

Dimana:

$\hat{\mathrm{Y}}=$ Kinerja Keuangan

$\mathrm{X}=$ Anggaran Berbasis Kinerja

$\mathrm{a}=$ Konstanta

$\mathrm{b}=$ Koefisien regresi dari variabel $\mathrm{X}$

Koefisien determinan $\left(\mathrm{R}^{2}\right)$ dimaksudkan untuk mengetahui tingkat ketepatan paling baik dalam analisis regresi, dimana hal yang ditunjukkan oleh besarnya koefisiensi determinasi $\left(\mathrm{R}^{2}\right)$ antara 0 (nol) dan 1 (satu). Koefisien determinasi $\left(\mathrm{R}^{2}\right)$ nol variabel independen sama sekali tidak berpengaruh terhadap variabel dependen, apabila koefisien determinasi semakin mendekati satu, maka dapat dikatakan bahwa variabel independen berpengaruh terhadap variabel dependen, selain itu koefisien detenninasi dipergunakan untuk mengetahui persentase perubahan variabel terikat $(\mathrm{Y})$ yang disebabkan oleh variabel bebas (X).

Untuk mengetahui seberapa besar pengaruh variabel $\mathrm{X}$ terhadap $\mathrm{Y}$, digunakan ramus koefisien determinasi $\left(\mathrm{R}^{2}\right)$ dengan cara mengkuadratkan nilai koefisien korelasi ( $\mathrm{r}$ ) yang telah dihitung dengan rumus sebagai berikut (Kerlinger dan Pedhazur, 1987) dalam Santoso (2007:35):

$$
\mathrm{KD}=\mathrm{r}^{2} \times 100 \%
$$

\section{Keterangan: \\ $\mathrm{KD}=$ Koefisien Determinasi \\ $\mathrm{r} \quad=$ Koefisien korelasi}

Berhubung didalam penelitian ini penulis menggunakan analisis regresi sederhana, maka yang digunakan hanya nilai statistik $t$. Uji $t$ digunakan untuk menguji signifikansi hubungan antara variabel $\mathrm{X}$ dan variabel $\mathrm{Y}$, apakah variabel $X$ benar-benar berpengaruh terhadap variabel Y. 
Hipotesis nol (Ho) yang hendak diuji adalah suatu parameter $(f t)$ sama dengan nol atau

$$
\mathrm{H}_{0}: \beta=0
$$

Artinya apakah suatu variabel independen bukan merupakan penjelas yang signifikan terhadap variabel dependen. Hipotesis alternatifnya $\left(\mathrm{H}_{\mathrm{a}}\right)$ parameter suatu variabel tidak sama dengan nol atau:

$$
\mathrm{H}_{\mathrm{a}}: \beta \# 0
$$

Artinya variabel independen merupakan penjelas yang signifikan terhadap variabel penjelas. Uji $\mathrm{t}$ ini dilakukan dengan menggunakan rumus sebagai berikut (Santoso, 2007: 36):

$$
t_{\text {hitung }} \frac{r \sqrt{n-2}}{\sqrt{1-r^{2}}}
$$

Keterangan:

$$
\begin{array}{ll}
\mathrm{t}_{\text {hitung }} & =\text { Nilai } \mathrm{t} \\
\mathrm{r} & =\text { Nilai koefisien korelasi } \\
\mathrm{n} & =\text { Jumlah sampel }
\end{array}
$$

Ketentuan:

1) Jika $t_{\text {hitung }}>t_{\text {tabel }}$ maka pengaruh variabel $X$ terhadap variabel $\mathrm{Y}$ mempunyai pengaruh yang signifikan.

2) Jika $t_{\text {hitung }}<t_{\text {tabel }}$ maka pengaruh variabel $X$ terhadap variabel $\mathrm{Y}$ mempunyai pengaruh yang tidak signifikan.

\section{HASIL PENELITIAN DAN \\ PEMBAHASAN}

\section{Penerapan Anggaran Berbasis Kinerja pada BPJ Wilayah Pelayanan V}

Berikut adalah tabel klasifikasi interval untuk memberikan gambaran mengenai penilaian terhadap Anggaran Berbasis Kinerja di Balai Pengelolaan Jalan (BPJ) Wilayah Pelayanan V:

Tabel 6: Klasifikasi Interval Anggaran Berbasis Kinerja

\begin{tabular}{|c|c|}
\hline Klasifikasi Interval & Penilaian \\
\hline $0-180$ & Tidak Baik \\
\hline $181-360$ & Kurang Baik \\
\hline $361-540$ & Cukup Baik \\
\hline $541-720$ & Baik \\
\hline $721-900$ & Sangat Baik \\
\hline
\end{tabular}

Sumber: Hasil Pengolahan Data
Berdasarkan tabel klasifikasi interval Anggaran Berbasis Kinerja, maka simpulan mengenai hasil kuesioner adalah sangat baik, karena skor yang diperoleh atas penilaian terhadap penerapan Anggaran Berbasis Kinerja adalah sebesar 865. Artinya penerapan Anggaran Berbasis Kinerja pada Balai Pengelolaan Jalan (BPJ) Wilayah Pelayanan V sudah dilaksanakan dengan sangat baik.

\section{Kinerja Keuangan BPJ Wilayah Pelayanan V}

Berikut adalah tabel klasifikasi interval untuk memberikan gambaran mengenai penilaian terhadap Kinerja Keuangan di Balai Pengelolaan Jalan (BPJ) Wilayah Pelayanan V:

Tabel 7: Klasifikasi Interval Kinerja Keuangan

\begin{tabular}{|c|c|}
\hline Klasifikasi Interval & Penilaian \\
\hline $0-60$ & Tidak Baik \\
\hline $61-120$ & Kurang Baik \\
\hline $121-180$ & Cukup Baik \\
\hline $181-240$ & Baik \\
\hline $241-300$ & Sangat Baik \\
\hline
\end{tabular}

Sumber: Hasil Pengolahan Data

Berdasarkan tabel klasifikasi interval Kinerja Keuangan, maka simpulan mengenai hasil kuesioner adalah sangat baik, karena skor yang diperoleh atas penilaian terhadap Kinerja Keuangan adalah sebesar 283. Artinya penerapan Kinerja Keuangan Balai Pengelolaan Jalan (BPJ) Wilayah Pelayanan V sudah dilakukan dengan sangat baik.

\section{Pengaruh Anggaran Berbasis Kinerja terhadap Kinerja Keuangan pada BPJ Wilayah Pelayanan V}

Berdasarkan hasil perhitungan Korelasi PPM menunjukan bahwa variabel independen Anggaran Berbasis Kinerja dengan variabel dependen Kinerja Keuangan memiliki hubungan yang kuat, karena nilai yang dihasilkan adalah sebesar 0,75 yang menurut Korelasi PPM nilai $r$ $=-1$ artinya korelasinya negatif sempurna; $r=0$ artinya tidak ada korelasi. Hasil analisis tersebut juga menghasilkan nilai $r$ yang positif, artinya antara Anggaran Berbasis Kinerja dengan Kinerja Keuangan memiliki hubungan yang kuat.

Sementara itu hasil perhitungan nilai $\mathrm{R}^{2}$ adalah sebesar 0,56 , hal tersebut menunjukan bahwa 56\% variabel dependen Kinerja Keuangan (Y) dapat dijelaskan oleh variabel independen Anggaran Berbasis Kinerja (X). 
Sedangkan sisanya sebesar 44\% (100\% - 56\%) dipengaruhi oleh sebab-sebab atau faktor-faktor lain diluar model.

Berdasarkan analisis statistik dalam penelitian ini dihasilkan nilai $t_{\text {hitung }}$ adalah sebesar 1,25. Sedangkan $t_{\text {tabel }}$ yang dihasilkan adalah sebesar 0,70 . Karena nilai $t_{\text {hitung }}$ lebih besar dibandingkan dengan nilai $t_{\text {tabel, }}$ yaitu 1,25 $>0,70$ artinya Hipotesis $\left(H_{a}\right)$ pada penelitian ini diterima, artinya ada pengaruh yang positif penerapan Anggaran Berbasis Kinerja terhadap Kinerja Keuangan pada Balai Pengelolaan Jalan (BPJ) Wilayah Pelayanan V.

Hasil penelitian ini sejalan dengan PP Nomor 105 tahun 2000 yang dalam pasal 8 dinyatakan bahwa APBD disusun dengan pendekatan kinerja. Penerapan anggaran berbasis kinerja pada instansi pemerintah di Indonesia dicanangkan melalui pemberlakuan UU nomor 17 tahun 2003 tentang keuangan nagara dan diterapkan secara bertahap mulai tahun anggaran 2005.

Pernyataan di atas yang menyatakan bahwa APBD yang mendasari penganggaran pada organisasi sektor public yang disusun dengan pendekatan kinerja tersebut diperkuat oleh pernyataan Mardiasmo (2002: 105) yang menyatakan bahwa "Performance budget pada dasarnya adalah sistem penyusunan dan pengolahan anggaran daerah yang berorientasi pada pencapaian hasil kerja atau kinerja". Kinerja tersebut mencerminkan efisiensi dan efektifitas pelayanan publik, yang berarti berorientasi pada kepentingan publik. Selanjutnya Mardiasmo (2002: 132) menyatakan "Pengertian efisiensi berhubungan erat dengan konsep produktifitas. Pengukuran efisiensi dilakukan dengan menggunakan perbandingan antara output yang dihasilkan terhadap input yang digunakan (cost of output)". Hasil penelitian ini pun sejalan atau sama dengan penilitian yang dilakukan oleh Lubis (2009), dimana hasil penelitiannya menjelaskan bahwa pemberlakuan Anggaran Berbasis Kinerja berpengaruh terhadap Kinerja Keuangan.

Dari pembahasan di atas, maka dapat disimpulkan bahwa anggaran berbasis kinerja berpengaruh positif terhadap kinerja keuangan secara teori. Hubungan kedua variabel tersebut, yaitu anggaran berbasis kinerja dan kinerja keuangan dapat diterima. Hasil ini mengindikasikan bahwa instansi menjalankan anggaran berbasis kinerja sebagai alat yang efisien dalam hubungannya dengan kinerja keuangan. Apabila anggaran berbasis kinerja dilaksanakan dengan baik, maka kinerja keuangan pun akan baik pula. Dengan kata lain ditemukan bukti anggaran berbasis kinerja sebagai faktor yang mempengaruhi kinerja keuangan.

\section{PENUTUP \\ Simpulan}

Berdasarkan hasil penelitian, simpulan dari pengaruh yang diberikan oleh variabel independen Anggaran Berbasis Kinerja terhadap variabel dependen Kinerja Keuangan adalah sebagai berikut:

1. Anggaran Berbasis Kinerja pada Balai Pengelolaan Jalan (BPJ) Wilayah Pelayanan $\mathrm{V}$ telah diterapkan dengan sangat baik. Artinya anggaran berbasis kinerja BPJ Wilayah Pelyanan V telah diterapkan secara efektif dan efisien.

2. Kinerja Keuangan Balai Pengelolaan Jalan (BPJ) Wilayah Pelayanan V sudah sangat baik. Artinya bahwa kinerja keuangan BPJ Wilayah Pelayanan V telah efektif, ekonomis dan efisien dalam penerapannya.

3. Anggaran Berbasis Kinerja berpengaruh positif dan signifikan terhadap Kinerja Keuangan Balai Pengelolaan Jalan (BPJ) Wilayah Pelayanan V. Artinya semakin baik penerapan anggaran berbasis kinerja pada BPJ Wilayah Pelayanan V, maka akan meningkatkan kinerja keuangan di BPJ Wilayah Pelayanan V.

\section{Saran}

Berikut adalah saran-saran yang diberikan oleh penulis dan diharapkan dapat dimanfaatkan oleh Balai Pengelolaan Jalan (BPJ) Wilayah Pelayanan V sebagai berikut:

1. BPJ Wilayah Pelayanan V sebaiknya lebih memperhatikan lagi penggunaan dana dengan cara menerapkan manajemen keuangan yang baik, sehingga capaian kegiatan/program efektif dan efisien.

2. BPJ Wilayah Pelayanan V sebaiknya lebih memperhatikan lagi faktor personal Sumber Daya Manusia (SDM) yang meliputi unsur pengetahuan, keterampilan, kemampuan, kepercayaan diri, motivasi dan komitmen yang dimiliki oleh setiap individu, dengan cara memberikan dorongan, semangat, arahan, dan dukungan kerja kepada karyawan, sehingga capaian kegiatan/program sesuai dengan tujuan yang telah dietapkan sebelumnya. 
3. BPJ Wilayah Pelayanan V sebaiknya lebih memperhatikan lagi sarana dan prasarana sebagai penunjang kegiatan program dengan cara mengoptimalkan fasilitas kerja dan infrastruktur, sehingga program kerja tersebut tepat sasaran.

4. BPJ Wilayah Pelayanan V sebaiknya lebih memperhatikan lagi kegiatan pembangunan jalan, dengan cara meningkatkan kualitas material jalan dan melaksanakan pembangunan sesuai dengan rencana, sehingga fasilitas jalan dapat digunakan tepat waktu dan memiliki kualitas yang baik.

5. BPJ Wilayah Pelayanan V sebaiknya lebih memperhatikan lagi pengadaan jasa sebagai penunjang program, dengan cara menerapkan prinsip transparansi dan partisipatif dalam kegiatan pengadaan jasa, sehingga jasa yang dibeli dapat dimanfaatkan dengan baik dalam kegiatan program.

6. Penelitian lebih lanjut terkait dengan variabel yang diteliti, maka agenda penelitian ke depan yaitu perlunya mencoba untuk meneliti variabel-variabel lain yang merupakan faktor-faktor lain yang dapat mempengaruhi kinerja keuangan. Selain itu, terkait dengan topik penelitian yang serupa, maka diharapkan pada penelitian ke depan dapat menggunakan data sampel dari beberapa jenis organisasi yang berbeda sehingga dapat memberikan hasil yang bervariasi karena adanya perbedaan karakter dari sampel yang diteliti.

\section{DAFTAR PUSTAKA}

Arikunto, S. 2006. Prosedur Penelitian Suatu Pendekatan Praktik. Jakarta: Rineka Cipta.

Bastian, I. 2006. Akuntansi Sektor Publik: Suatu Pengantar. Jakarta: Erlangga.

Djuanda, Gustin dan Lubis, Irwansyah. 2009. Pelaporan Pajak Penghasilan. Jakarta : PT Gramedia Utama.

Espinoza. 2014. Pengaruh Penerapan Anggaran Berbasis Kinerja Terhadap Kinerja Keuangan Pemerintah Kota Medan. Skripsi. Medan: Universitas Sumatra Utara.

Mardiasmo. 2002. Otonomi dan Manajemen Keuangan Daerah. Yogyakarta: ANDI.

Santoso, Singgih. 2003. Mengatasi Berbagai Masalah Statistik dengan SPSS versi 11.5. Jakarta. PT. Elex Media Komputindo.
2007. Statistik Deskriptif: Konsep dan Aplikasi dengan. Microsoft Exel dan SPSS. Yogyakarta: ANDI.

Sugiyono. 2010. Metode Penelitian Bisnis. Bandung: CV Alfabeta. 